\title{
Tinjauan Yuridis Terhadap Perubahan Kewenangan Pengawasan Ketenagakerjaan Dari Pemerintah Kabupaten/Kota Kepada Pemerintah Provinsi Jawa Tengah
}

\author{
Sonhaji \\ Fakultas Hukum, Universitas Diponegoro \\ sonhaji@gmail.com
}

\begin{abstract}
The research aims to determine the juridical review of changes in the authority of labor inspection from the Regency / City Government to the Central Java Provincial Government. The research method used is the legal research method. the results of the study show that the transfer of labor inspection authority to the Department of Manpower and Transmigration of Central Java Province, made labor inspection activities not yet / less effective. This can be seen since 2017 the number of supervisory staff has decreased, which in 2014 amounted to 585 employees while in 2017 there were only 154 employees, and there was no additional funding budgeted for Central Java Province, which should have been done when the number of activities had to done increasing or increasing. Consequently the performance of supervisory staff and the number of findings of labor violations has decreased.
\end{abstract}

Keywords: Effectiveness, Supervision, Employment.

\begin{abstract}
Abstrak
Penelitian bertujuan untuk mengetahui tinjauan yuridis terhadap perubahan kewenangan pengawasan ketenagakerjaan dari Pemerintah Kabupaten/Kota Kepada Pemerintah Provinsi Jawa Tengah Metode penelitian yang digunakan adalah metode penelitian hukum. hasil penelitian menunjukan bahwa Pengalihan kewenangan pengawasan ketenagakerjaan kepada Dinas Tenaga Kerja dan Transmigrasi Provinsi Jawa Tengah, menjadikan kegiatan pengawasan ketenagakerjaan belum/kurang efektif. Hal ini dapat dilihat sejak tahun 2017 jumlah pegawai pengawas mengalami penurunan, yang mana pada Tahun 2014 berjumlah 585 pegawai sedangkan pada Tahun 2017 hanya berjumlah 154 pegawai, dan tidak adanya dana tambahan yang dianggarkan untuk Provinsi Jawa Tengah, yang seharusnya dilakukan ketika jumlah kegiatan yang harus dilakukan bertambah atau meningkat. Konsekuensinya kinerja pegawai pengawas dan jumlah temuan pelanggaran ketenagakerjaan mengalami penurunan.
\end{abstract}

Kata kunci : Efektivitas, Pengawasan, Ketenagakerjaan. 


\section{A. Pendahuluan}

Manusia guna memenuhi hajat hidup baik untuk diri sendiri maupun untuk orang banyak pasti membutuhkan pekerjaan. Dalam usaha pemenuhannya tersebut manusia sebagai homofaber tidak akan lepas oleh peraturan-peraturan yang mengikat setiap pekerjaannya. Peraturan ini sendiri dibentuk oleh pemerintah untuk mewujudkan keteraturan dalam setiap elemen sosial masyarakat guna terwujudnya pembangunan nasional yang menjadi tujuan Bangsa Indonesia. Pembangunan merupakan setiap upaya yang dikerjakan secara terencana untuk melaksanakan perubahan yang memiliki tujuan utama untuk memperbaiki dan menaikan taraf hidup, kesejahteraan dan kualitas manusia. ${ }^{1}$

Sistem Jaminan Sosial Nasional adalah suatu tata cara penyelenggaraan program jaminan sosial oleh beberapa badan penyelenggara jaminan sosial. Sistem Jaminan Sosial Nasional pada dasarnya merupakan program Negara yang bertujuan memberi kepastian perlindungan dan kesejahteraan sosial bagi seluruh rakyat Indonesia. Melalui program ini, setiap penduduk diharapkan dapat memenuhi kebutuhan dasar hidup yang layak apabila terjadi hal-hal yang dapat mengakibatkan hilang atau berkurangnya pendapatan, karena menderita sakit, mengalami kecelakaan, kehilangan pekerjaan, memasuki usia lanjut, atau pensiun. Jaminan sosial merupakan salah satu hak asasi manusia yang pada prinsipnya adalah seperangkat hak yang melekat pada hakikat dan keberadaan manusia sebagai makhluk Tuhan Yang Maha Esa dan merupakan anugerah-Nya yang wajib dihormati, dijunjung tinggi dan dilindungi oleh Negara, hukum, pemerintah, dan setiap orang demi kehormatan serta perlindungan harkat dan martabat manusia. $^{2}$

Kebijakan mengenai ketenagakerjaan terus diupayakan guna menciptakan kesempatan kerja yang seluas-luasnya di berbagai bidang dengan peningkatan mutu dan perlindungan terhadap tenaga kerja yang bersifat menyeluruh pada semua sektor. Hal ini merupakan satu bentuk campur tangan

\footnotetext{
1 Ali Muhammad. 2009. Pendidikan Untuk Pembangunan Nasional Menuju Bangsa Indonesia yang Mandiri dan Berdaya Saing Tinggi. Bandung: PT Imperial Bakti Utama

2 Suhartoyo. Perlindungan Hukum Bagi Pekerja Peserta BPJS Kesehatan di Rumah Sakit. Adminitrative Law \& Governance Journal Vol. 1 Edisi 2 Mei 2018
} 
negara dalam melindungi hak-hak dasar pekerja/buruh dengan memperhatikan akibatnya terhadap kemajuan negara. ${ }^{3}$ Dengan wujud campur tangan negara, maka pelaksanaan asas kebebasan berkontrak antara pengusaha dan pekerja/buruh dalam perjanjian kerja menjadi sangat terbatas. ${ }^{4}$ Hal ini berarti bahwa setiap warga Negara berhak mendapatkan jaminan sosial untuk dapat mengembangkan dirinya secara utuh sebagai manusia yang bermartabat. $^{5}$ Negara diizinkan melakukan pembatasan yang masuk akal terhadap hak ini, untuk melindungi orang lain karena dalam proses pembangunan nasional terlebih bdidang ketenagakerjan tentu akan ada permasalahan yang ditimbulkan. ${ }^{6}$

Permasalahan ini pula dapat tercover secara cepat jika adanya pelaksanaan pengawasan yang baik dan efektif. Pada kenyataan untuk melakukan pengawasan yang efektif juga banyak mengalami permasalahan. Permasalahan terkait pengawasan ketenagakerjaan bisa ditimbulkan dari berbagai aspek, seperti dari dampak globalisasi, Perkembangan ekonomi global dan kemajuan teknologi yang demikian cepat membawa dampak timbulnya persaingan usaha yang begitu ketat dan terjadi di semua aspek.

Persaingan dalam dunia bisnis antar perusahaan, membuat perusahaan harus berkonsentrasi pada rangkaian proses atau aktivitas penciptaan produk dan jasa yang terkait dengan kompetensi utamanya. Dengan adanya konsentrasi terhadap kompetensi utama dari perusahaan maka akan dihasilkan sejumlah produk dan jasa berkualitas yang memiliki daya saing di pasaran. ${ }^{7}$ Sehingga dalam pemenuhannya perusahaan perlu mempekerjakan tenaga asing untuk bidang-bidang tertentu yang tidak dapat tercover oleh tenaga

\footnotetext{
3 Sonhaji, “Analisis Putusan Mahkamah Agung Nomor 501 K/ PDT.SUS-PHI/ 2016 Tentang Pemutusan Hubungan Kerja", Administrative Law \& Governance Journal, Vol.1 Edisi Khusus I 2018.

4 Sonhaji, "Analisis Putusan Mahkamah Agung Nomor 501 K/ PDT.SUS-PHI/ 2016 Tentang Pemutusan Hubungan Kerja", Administrative Law \& Governance Journal, Vol.1 Edisi Khusus I 2018.

5 Suhartoyo. Perlindungan Hukum Bagi Pekerja Peserta BPJS Kesehatan di Rumah Sakit. Adminitrative Law \& Governance Journal Vol. 1 Edisi 2 Mei 2018

6 Suhartoyo, "Penguatan Organisasi Buruh / Pekerja Sebagai Sarana Perlindungan Buruh" , Administrative Law \& Governance Journal, Vol.1 Edisi 4, November 2018.

7 Sonhaji, "Analisis Putusan Mahkamah Agung Nomor 501 K/ PDT.SUS-PHI/ 2016 Tentang Pemutusan Hubungan Kerja", Administrative
} 
kerja Indonesia. Tindakan perusahaan ini memang dirasa perlu karena merupakan suatu kebutuhan bagi pembangunan Negara Indonesia. Namun yang perlu diingat adalah penggunaan tenaga asing harus dipekerjakan untuk memajukan negara Indonesia sesuai dengan cita - cita Bangsa.

Proses pembangunan nasional dalam pelaksanaannya akan banyak mengalami indikasi pergeseran nilai atau aturan yang dapat dilanggar oleh pelaksananya. ${ }^{8}$ Untuk mengantisipasi proses pergeseran nilai dan aturan ini maka adanya pengawasan ketenagakerjaan sangat diperlukan. Hal ini bertujuan sebagai upaya untuk mencegah, menjaga serta membantu permasalahan tenaga kerja yang dilakukan secara efektif dan efisien. Sehingga langkah - langkah antisipatif dari para pihak yang berkaitan dengan ketenagakerjaan dapat dilakukan dengan baik. pengawasan yang dilakukan oleh pegawai pemerintah dirasa sangat penting untuk dilakukan untuk menjamin terpenuhinya hak dan kewajiban pekerja/buruh. ${ }^{9}$ Dengan pengawasan ketenagakerjaan ini juga mampu membuat peningkatan mutu ketenagakerjaan menjadi nyata.

Penyempurnaan sistem pengawasan terhadap ketenagakerjaan ini, merupakan strategi dalam penanganan permasalahan pembangunan nasional yang ada hingga saat ini seringkali perselisihan terjadi disebabkan karena tidak terpenuhinya hak masing-masing pihak dalam perjanjian kerja ataupun tidak terlaksananya perjanjian kerja yang telah disepakati oleh semua pihak. ${ }^{10}$ penyempurnaan sistem pengawasan dirasa menjadi lebih tidak optimal dan dibatasi ruang lingkupnya sejak diberlakukannya Undang-Undang Nomor 23 Tahun 2014 Tentang Pemerintahan Daerah. Hal ini disebabkan pengaturan pengawasan didalam Undang-Undang Nomor 23 Tahun 2014 tentang Pemerintahan Daerah menjadi dasar dialihkannya kewenangan pengawasan ketenagakerjaan yang awalnya berada di Pemerintah Kabupaten/Kota kini berada di Pemerintah Provinsi. Hal ini tentu akan menimbulkan perdebatan di

\footnotetext{
${ }^{8}$ Rusli Hardijan. 2009. Hukum Ketenagakerjaan. Jakarta: Ghalia Indonesia

${ }^{9}$ Soekanto, Soerjono dan Sri Mamudji. 2004. Penelitian Hukum Normatif Suatu Tinjauan Singkat. Jakarta: PT. Raja Grafindo Persada.

10 Indriana.Pelaksanaan Tugas DInas Tenaga Kerja Dalam Pengawasan Keselamatan Dan Kesehatan Kerja Di Kota Makassar.2008. Hal. 4
} 
masyarakat dan menjadi pertanyaan, mengapa kewenangan tersebut harus dialihkan.

Berdasarkan pada permasalahan di atas, maka penulis tertarik untuk membahas dan meneliti terkait pelaksanaan pengawasan ketenagakerjaan. Sehingga dengan dilakukannya penulisan hukum ini penulis diharapkan dapat menguraikan bagaimana efektivitas pengawasan ketenagakerjaan yang dilakukan oleh Dinas Tenaga Kerja dan Transmigrasi Provinsi Jawa Tengah. Dengan fokus pada bagaimana efektivitas pengawasan yang akan diterapkan oleh Pemerintah Daerah Provinsi Jawa Tengah terhadap ketenagakerjaan setelah adanya pengalihan kewenangan dari Pemerintah Kabupaten/Kota kepada Pemerintah Provinsi. Apa saja faktor penghambat pelaksanaan pengawasan oleh Pemerintah Daerah Provinsi Jawa Tengah terhadap ketenagakerjaan setelah adanya pengalihan kewenangan dari Pemerintah Daerah Kabupaten/Kota kepada Pemerintah Provinsi.

\section{Metode}

Metode pendekatan yang digunakan dalam penelitian ini adalah metode yuridis empiris. Penelitian yuridis empiris yakni dilakukan dengan melihat kenyataan yang ada di dalam lapangan dengan berbasis ilmu hukum normatif, yang mengkaji peraturan dalam pelaksanaannya di masyarakat dengan memadukan data ataupun fakta yang telah diperoleh di dalam sebuah penelitian. Penelitian ini sering disebut juga dengan penelitian bekerjanya hukum (law in action). Pendekatan yuridis dalam penelitian ini dimaksudkan bahwa penelitian ini ditinjau dari sudut ilmu hukum administrasi negara dan peraturan-peraturan tertulis lainnya yang berhubungan dengan pengawasan ketenagakerjaan yang seharusnya dilaksanakan.

Pendekatan empiris adalah penelitian yang bertujuan untuk memperoleh pengetahuan empiris tentang hubungan dan pengaruh hukum, sebagai alat untuk mengatur masyarakat dengan melakukan penelitian langsung terhadap subyek penelitian sebagai data primer tempat memperoleh data sebagai sumber pertama. Penelitian ini berupa studi empiris untuk menemukan teori- 
teori mengenai proses terjadinya dan mengenai proses bekerjanya hukum di dalam masyarakat. ${ }^{11}$

Spesifikasi penelitian yang digunakan penulis dalam membedah permasalahan pada penulisan hukum ini adalah deskriptif analitis. Dalam metode deskriptif dapat diteliti masalah normatif bersama-sama dengan masalah dan sekaligus membuat perbandingan-perbandingan antar fenomena. ${ }^{12}$ Analisis penelitian ini diharapkan dapat melihat suatu hal yang ada didalam teori dan praktek sehingga diharapkan dapat memecahkan permasalahan yang telah ada, yakni mengenai pelaksanaan pengawasan ketenagakerjaan oleh Dinas Tenaga Kerja dan Transmigrasi Provinsi Jawa Tengah. Jadi dapat dikatakan bahwa dalam penulisan hukum ini penulis mengungkapkan hasil penelitian dalam bentuk uraian yang menjelaskan fakta dan data yang ditemui di lapangan.

Metode penentuan sampel yang digunakan dalam penelitian ini adalah teknik non random sampling, dalam penelitian kualitatif teknik sampling yang lebih sering digunakan yaitu purposive sampling. Purpose sampling atau penarikan sampel dilakukan bertujuan dilakukan dengan cara mengambil subyek didasarkan pada tujuan tertentu. Teknik ini dipilih karena alasan keterbatasan waktu, tenaga dan biaya sehingga tidak dapat mengambil sampel yang besar jumlahnya. ${ }^{13}$

Dalam melakukan penelitian ini penulis menggunakan data primer dan data sekunder. Data primer adalah sumber data penelitian yang diperoleh secara langsung dari lapangan yang terkait dengan pelaksanaan pengawasan ketenagakerjaan oleh Dinas Tenaga Kerja dan Transmigrasi Provinsi Jawa Tengah. Adapun data primer ini diperoleh dengan cara wawancara langsung dengan Kepala Bidang Hubungan Industrial dan Jaminan Sosial Dinas Tenaga Kerja dan Transmigrasi Kota Semarang dan Kepala Seksi Bidang Pengawasan Ketenagakerjaan Dinas Tenaga Kerja dan Transmigrasi Provinsi

11 Sunggono, Bambang, Metodologi Penelitian Hukum, (Jakarta: PT. Raja Grafindo Persada, 2003), halaman 42

${ }^{12}$ Moh. Nazir, Metode Penelitian, Jakarta:Ghalia Indonesia, 2003, hlm. 55.

13 Nur Diantoro dan Bambang Supomo, Metodologi Penelitian Bisnis Untuk Akuntansi \& Manajemen, Yogyakarta: BPFE-Yogyakarta, 1999, hlm. 147. 
Jawa Tengah. Sedangkan data sekunder itu sendiri adalah sumber data penelitian yang diperoleh secara tidak langsung melainkan melalui buku, catatan, hasil penelitian.

Metode dapat diartikan sebagai proses, cara, prosedur yang digunakan untuk menyelesaikan suatu permasalahan. Metode yang digunakan untuk mengumpulkan data dalam penelitian ini yaitu studi kepustakaan, observasi dan wawancara. Pengumpulan data dalam studi kepustakaan merupakan kegiatan menulusuri, memeriksa, mengkaji data-data sekunder. Metode observasi adalah metode pengumpulan data dengan mengamati secara langsung di lapangan. Dalam hal ini mengamati bukan hanya melihat namun juga merekam, menghitung, mengukur, dan mencatat kejadian-kejadian yang ada. Metode wawancara adalah metode pengumpulan data yang menggunakan cara dengan memberikan sebuah pertanyaan dengan tatap muka dengan objek yang akan diteliti untuk memperoleh keterangan yang diinginkan dalam penelitian. Metode ini digunakan peneliti guna memperoleh data yang akurat dari sumber yang terpercaya.

Pengolahan dan analisis data dalam penelitian ini dilakukan dengan metode analisis kualitatif yaitu proses analisa terhadap data dari keadaan yang nyata dalam kehidupan sehari-hari bukanlah data yang terdiri dari katakata yang dapat ditafsirkan. ${ }^{14}$ Maksud dari proses analisis ini yakni penulis berusaha untuk memahami terhadap data yang diperoleh, kemudian menyampaikannnya kepada orang lain yang membacanya supaya lebih jelas tentang apa yang telah didapatkan dari hasil penelitian lapangan.

Penyajian data merupakan salah satu kegiatan dalam pembuatan laporan hasil penelitian yang telah dilakukan agar dapat dipahami dan dianalisis seusia dengan tujuan yang diinginkan maka dilakukan editing. Ada beberapa jenis cara untuk menyajikan data, yang pertama dengan cara menyajikan data dalam bentuk tulisan dan yang kedua menyajikan data dalam bentuk tabel dan grafik. Tabel merupakan kumpulan angka-angka yang disusun menurut kategori-kategori (misalnya: jumlah pemeriksaan oleh pegawai pengawas

${ }^{14}$ Bungin Burhan. Metode Penelitian Kuantitatif. Jakarta: Kencana. 2011 
Dinas Tenaga Kerja dan Transmigrasi Provinsi Jawa Tengah) sehingga memudahkan dalam pembuatan analisis data. Data yang sudah diperoleh, kemudian dianalisis dengan menggunakan metode analisis kualitatif. Hasil analisa ini selanjutnya disajikan dalam bentuk diskriptif agar para pembaca mudah mengerti gambaran mengenai jumlah pemeriksaan oleh pegawai pengawas Dinas Tenaga Kerja dan Transmigrasi Provinsi Jawa Tengah.

\section{B. Pembahasan}

Dari penelitian yang dilakukan menghasilkan bahwa pengawasan ketenagakerjaan pengawasan pada dasarnya dibagi menjadi dua macam, yaitu pengawasan internal dan pengawasan eksternal. Pegawai pengawas internal dapat berupa unit atau monitoring dan pengendalian ataupun badan pengawas daerah. Pegawai pengawas eksternal dapat berupa DPRD, LSM, dinas terkait, dan komponen masyarakat. ${ }^{15}$

Karakteristik pengawasan ketenagakerjaan tersebut apabila disandingkan dengan teori dari Wolfgang Von Richthoven jelas bahwa Indonesia menganut Sistem Integrasi fungsional karena tercermin pada tindak lanjut dari penemuan pelanggaran berupa tindakan preventif (pembinaan, penyuluhan, dan pelatihan), represif nonjusticia (pemenuhan atau compliance terhadap sanksi yang dilanggar, penerapan sanksi administratif), atau represif justicia (di selesaikan melalui jalur pengadilan). ${ }^{16}$

Pengawasan ketenagakerjaan juga dikaitkan dengan otonomi daerah yang dalam hal ini diasumsikan sebagai pengalihan kewenangan pengawasan ketenagakerjaan, hal itu berimplikasi bahwa studi dan penilaian terhadap otonomi daerah haruslah dilakukan terhadap para pelaku dan institusi yang menerima pengalihan fungsi-fungsi yaitu daerah. mengarahkan perhatian pada kondisi pemerintah daerah, institusi daerah dan sikap-sikap kepala daerah terhadap program otonomi daerah. ${ }^{17}$

\footnotetext{
${ }^{15}$ Hadi Prabowo. Wawancara Kepala Seksi Bidang Pengawasan Ketenagakerjaan Dinas Tenaga Kerja dan Transmigrasi Provinsi Jawa Tengah. (Semarang, 15 Februari 2019)

16 Safri Nugraha. Hukum Administrasi Negara: Edisi Revisi, Center For Law and Good Governance Studies (CLGSFHUI). Jakarta: Ghalia Indonesia. 2007

${ }^{17}$ Mas'ud Said, Arah Baru Otonomi di Indonesia, UMM Press, Malang: 2008, hlm 58
} 
Penelitian ini akan menjelaskan empat jenis pengawasan yang dilakukan oleh Dinas Tenaga Kerja dan Transmigrasi Provinsi Jawa Tengah setelah adanya pengalihan kewenangan pengawasan ketenagakerjaan yaitu; pengawasan pertama, pengawasan berkala, pengawasan ulang dan pengawasan khusus. Jenis-jenis pengawasan ini dilakukan sesuai dengan tujuan masingmasing untuk apa pengawasan itu dilakukan. Dari hasil penelitian di Dinas Tenaga Kerja dan Transmigrasi Provinsi Jawa Tengah didapat data keempat jenis pengawasan yang dilakukan pada Tahun 2014 dan Tahun 2017.

Badan Pusat Statistik Jawa Tengah menyebutkan jumlah perusahaan yang berada di Jawa Tengah dengan skala kecil-menengah ada sebanyak 61.461 perusahaan. ${ }^{18}$ Jika dikaitkan dengan data di atas antara jumlah pegawai pengawas dengan jumlah perusahaan yang harus diawasi sudah tentu memiliki perbedaan yang sangat jauh. Data hasil penelitian menunjukan setelah adanya pengalihan kewenangan pengawasan ketenagakerjaan, jumlah pegawai pengawas mengalami pengurangan dari seluruh Kota/Kabupaten di Jawa Tengah.

Pegawai pengawas yang awalnya berjumlah 585 pada Tahun 2014 setelah adanya pengalihan kewenangan pengawasan ketenagakerjaan menjadi 154 pegawai pengawas pada Tahun 2017. Dengan berkurangnya jumlah pegawai pengawas pada Tahun 2017 hanya sebanyak 154 pegawai dan harus mengawasi jumlah perusahaan di Jawa Tengah sebanyak 61.461 yang mana ini masih dalam skala kecil dan menengah belum termasuk dalam skala perusahaan besar, sudah tentu pengawasan tidak akan berjalan efektif. Jika dilihat dengan data yang disajikan di atas berarti perhitungannya 1 orang pegawai pengawas harus mengawasi sekitar 399 perusahaan. Hal ini tentu tidak ideal dan dalam praktiknya tidak akan berjalan efektif karena 1 pegawai pengawas tidak mungkin mampu mengawasi 399 perusahaan sekaligus. ${ }^{19}$

Jumlah perusahaan dengan skala kecil dan menengah yang ada di Jawa Tengah sekitar 61.461 maka idealnya jumlah pegawai harus ditambah menjadi

\footnotetext{
${ }^{18} \mathrm{Http}$ ://semarangkota.bps.go.id. Diakses pada 15 Januari 2019 Pukul 13.20 WIB

${ }_{19}$ Budi Astuti. Wawancara Kepala Bidang Hubungan Industrial dan Jaminan Sosial, Dinas Tenaga Kerja dan Transmigrasi Kota Semarang. (Semarang, 4 Februari 2019)
} 
1230 pegawai dengan perbandingan 1 orang pegawai mengawasi 50 perusahaan. Dengan jumlah yang ada dapat kita lihat bagaimana kemampuan kinerja pegawai pengawas dapat kita lihat pada data tabel di atas. Pada pelaksanaan pengawasan pertama, pengawasan adalah pengawasan yang dilakukan untuk pertama kalinya biasanya untuk perusahaan yang baru saja berdiri, dilakukan oleh tim yang dibentuk oleh seksi pengawasan norma kerja (sebagai koordinator) bersama dengan pegawai fungsional, setiap pelaksanaan pengawasan ini bergantung pada rencana kerja dan biasanya pengawasan ini tidak dapat ditentukan terhadap pengawasan perusahaan. Tujuan dari pengawasan ini untuk mengetahui penyimpangan-penyimpangan dan semua desas-desus tentang suatu perusahaan, seperti mendirikan, menjalankan kembali atau memindahkan perusahaan. Pada tabel di atas menunjukan Tahun 2014 pegawai pengawas yang masih berada di Kabupten/Kota mampu melakukan pengawasan kepada perusahaan sebanyak 624, setelah adanya pengalihan pegawai pengawas yang berada di Provinsi melakukan pengawasan kepada perusahaan sebanyak 810 perusahaan. ${ }^{20}$

Kegiatan pengawasan berikutnya yaitu pengawasan berkala dilakukan oleh Dinas Tenaga Kerja dan Transmigrasi Provinsi Jawa tengah setiap 6 bulan sekali untuk pengawasan ke perusahaan di Jawa Tengah. Pengawasan ini bertujuan meminimalisirkan kecelakaan kerja dan memberikan suatu pengetahuan khusus untuk pencegahan kecelakaan kerja. Dari data tabel di atas dapat dilihat ada 2744 perusahaan yang dapat diawasi oleh pegawai pengawas pada Tahun 2014 sedangkan pada Tahun 2017 sebanyak 727 perusahaan, adanya penurunan kinerja pegawai pengawas setelah adanya pengalihan kewenangan pengawasan, pegawai pengawas hanya mampu melakukan pengawas berkala (pengawasan pada semua perusahaan) hanya sebanyak 727 pemeriksaan, keterbatasan mengawasi secara menyeluruh pada semua perusahaan setiap 6 bulan sekali ini sudah tentu dilandasi faktor utama yaitu kurangnya jumlah pegawai pengawas dan banyaknya perusahaan yang harus diawasi. Jarak yang berjauhan antara pegawai pengawas dengan perusahaan

${ }^{20}$ Hadi Prabowo. Wawancara Kepala Seksi Bidang Pengawasan Ketenagakerjaan Dinas Tenaga
Kerja dan Transmigrasi Provinsi Jawa Tengah. (Semarang, 15 Februari 2019) Administrative Law \& Governance Journal. Volume 2 Issue 2, June 2019 
yang akan diawasi tentu tidak akan mampu dilakukan sekaligus dalam sekali pengawasan, ini juga tentu akan memakan banyak waktu dan biaya. ${ }^{21}$

Pemeriksaan ulang yaitu pemeriksaan yang dikakukan oleh Dinas Tenaga Kerja dan Transmigrasi Provinsi Jawa Tengah terhadap perusahaan yang telah dilakukan pemeriksaan sebelumnya, namun masih terdapat pelanggaran yang terjadi. Pada Tahun 2014 ada 7 perusahaan yang dilakukan pemeriksaan ulang sedangkan pada Tahun 2017 tidak ada perusahaan yang dilakukan pemeriksaan ulang. Pemeriksaan khusus dilakukan hanya pada saat ada pengaduan atau kasus yang tejadi di lapangan saat kecelakaan kerja terjadi di suatu perusahaan. Artinya pengawasan ini langsung saat itu juga dilakukan saat kecelakaan kerja terjadi di suatu perusahaan. ${ }^{22}$

Pelaku yang bertugas untuk pengawasan ini adalah pegawai pengawas seksi bidang keselamatan dan kesehatan kerja serta jajaran staf jabatan fungsional pengawas ketenagakerjaan. Pengawasan ini bertujuan melakukan penyidikan atas kasus yang sedang dialami oleh pegawai atau pekerja yang mengalami kecelakaan kerja untuk mengetahui penyebab terjadinya kecelakaan kerja. Berkaitan dengan ini pada Tahun 2014 pegawai dapat melakukan pengawasan terhadap 355 perusahaan sedangkan hanya 33 perusahaan yang mampu diawasi pada Tahun 2017. Perbandingan yang sangat jauh ini tentu dapat menjadi tolok ukur bagaimana kesigapan pegawai pengawas dalam menangani kecelakaan atau pelanggaran dalam suatu perusahaan yang terjadi saat itu juga. Jarak yang dekat antara pegawai pengawas dengan perusahaan yang harus diawasi pada Tahun 2014, dapat menghasilkan pelayanan dan penanganan yang lebih banyak dibandingkan pada Tahun 2017. Ini juga tentu dapat menjadi tolok ukur keefektif-an suatu pengawasan ketenagakerjaan.

Jumlah perusahaan yang harus diawasi sebanyak 61.461 dengan berkurangnya jumlah pegawai pengawas secara tidak langsung mempengaruhi kemampuan kinerja pengawai pengawas untuk melakukan kegiatan pengawasan.

\footnotetext{
${ }^{21}$ Hadi Prabowo. Wawancara Kepala Seksi Bidang Pengawasan Ketenagakerjaan Dinas Tenaga Kerja dan Transmigrasi Provinsi Jawa Tengah. (Semarang, 15 Februari 2019)

${ }^{22}$ Hadi, Prabowo. Ibid
} 
Sehingga dalam pelaksanaannya pegawai pengawas membuat suatu sistem skala prioritas untuk setiap perusahaan yang melapor kepada Dinas Tenaga Kerja dan Transmigrasi Provinsi Jawa Tengah.pengawasan dengan skala prioritas ini dilakukan pada awalnya adalah secara menyeluruh pada semua perusahaan yang ada di masing-masing kabupaten/kota, namun jika ada laporan yang masuk ke Disnakertrans Provinsi Jawa Tengah terkait dengan perusahaan yang berada di kabupaten/kota tertentu, maka perusahaan itu akan masuk dalam skala prioritas dan akan diawasi serta ditindaklanjuti terlebih dahulu dibandingkan dengan perusahaan-perusahaan yang tidak melapor adanya pelanggaran di perusahaannya kepada Disnakertrans Jawa Tengah. ${ }^{23}$

Kondisi pemerintah daerah, institusi daerah dan sikap-sikap kepala daerah terhadap pengawasan dalam hal ini yang dimaksud adalah program otonomi daerah jika yang bermasalah karena ketidakmampuannya dalam menjalakan perkerjaannya disebabkan adanya kolusi antara pemerintah daerah dengan perusahaan, maka menurut penulis yang seharusnya dibenahi adalah SDM yang ada di daerah, bukan dengan melakukan pengalihan kewenangan dari pemerintah kabupaten/kota ke provinsi. Kegagalan pengimplementasian otonomi daerah terutama di negara-negara berkembang seringkali karena, meski pelaksaannya telah direncanakan secara memadai, namun dijalankan secara buruk oleh pemerintah daerah yang tak berpengalaman dan PNS yang tak cakap. ${ }^{24}$ Keberhasilan suatu organisasi dalam mencapai tujuan tergantung pada perilaku dan sikap orang-orang, keandalan dan kemampuan orang-orang yang mengoperasikan unit-unit kerja yang terdapat dalam organisasi tersebut. ${ }^{25}$ Jadi dalam pelaksanaan pengawasan ketenagakerjaan, agar dapat berjalan dengan baik, maka harus dijalankan oleh aparat atau PNS yang berkompeten.

Fakta lain di lapangan sesuai dengan hasil penelitian yang penulis lakukan, pengalihan kewenangan dari Pemerintah Kabupaten/Kota kepada Pemerintah

${ }^{23}$ Hadi Prabowo. Wawancara Kepala Seksi Bidang Pengawasan Ketenagakerjaan Dinas Tenaga Kerja dan Transmigrasi Provinsi Jawa Tengah. (Semarang, 15 Februari 2019)

${ }^{24}$ Mas'ud Said, Ibid, hlm. 61

25 Widya Astuti, "Pengaruh Perilaku Kepemimpinan pada Kinerja Pegawai Dinas Tata Kota Pekanbaru", Jurnal Ilmu Administrasi Negara, Program Studi Ilmu Administrasi PPS Universitas Riau, Volume 8, No. 2, Juli 2008, hlm. 73 
Provinsi tidak menunjukan adanya signifikansi dari sisi kinerja pegawai pengawas. Sehingga dari data dan hasil wawancara menunjukkan pengawasan ketenagakerjaan yang dilakukan setelah adanya pengalihan kewenangan adalah kurang/belum efektif. Pernyataan ini didasarkan hasil wawancara dengan Ibu Budi Astuti, Kepala Bidang Hubungan Industrial dan Jaminan Sosial Disnakertrans Kota Semarang, mengatakan pengalihan kewenangan pengawasan ketenagakerjaan sangat tidak efektif, dikarenakan tujuan dari pembagian urusan pemerintah ke daerah Kabupaten/Kota adalah untuk mewujudkan pengawasan ketenagakerjaan yang efektif namun setelah terpusatnya kewenangan pada Pemerintah Provinsi membuat Disnakertrans Kota Semarang tidak memiliki wewenang apapun terhadap pelanggaran yang terjadi di Kota Semarang sehingga Disnakertrans tidak memiliki peran apapun dalam pembangunan di bidang pengawasan ketenagakerjaan. ${ }^{26}$

Pengawasan ketenagakerjaan ini juga terkendala karena adanya hambatan yang dialami hambatan-hambatan yaitu kurangnya jumlah pegawai pengawas, dan kurangnya dana yang tersedia serta kurangnya sarana dan prasarana untuk melakukan pengawasan ketenagakerjaan. Sedangkan upaya yang dilakukan untuk mengatasi hambatan tersebut adalah melakukan pengawasan ketenagakerjaan dengan skala prioritas, kemudian kurangnya dana, pegawai pengawas masih menggunakan uang pribadi untuk menutupi kekurangan, serta masih diupayakannya penambahan sarana dan prasarana oleh pemerintah untuk pengadaan dan penggunaan sarana dan prasarana meliputi alat keselamatan dan kesehatan kerja, perlengkapan alat tulis kantor, fasilitas transportasi dan aggaran yang cukup sangat di butuhkan dalam pelaksanaan pengawasan.

\section{Simpulan}

Pengalihan kewenangan pengawasan ketenagakerjaan kepada Dinas Tenaga Kerja dan Transmigrasi Provinsi Jawa Tengah, menjadikan kegiatan pengawasan ketenagakerjaan belum/kurang efektif. Hal ini dapat dilihat sejak tahun 2017 jumlah pegawai pengawas mengalami penurunan, yang mana pada

\footnotetext{
${ }^{26}$ Budi Astuti. Wawancara Kepala Bidang Hubungan Industrial dan Jaminan Sosial, Dinas Tenaga Kerja dan Transmigrasi Kota Semarang. (Semarang, 4 Februari 2019)
} 
Tahun 2014 berjumlah 585 pegawai sedangkan pada Tahun 2017 hanya berjumlah 154 pegawai, dan tidak adanya dana tambahan yang dianggarkan untuk Provinsi Jawa Tengah, yang seharusnya dilakukan ketika jumlah kegiatan yang harus dilakukan bertambah atau meningkat. Konsekuensinya kinerja pegawai pengawas dan jumlah temuan pelanggaran ketenagakerjaan mengalami penurunan.

Hambatan-hambatan yang dihadapi oleh Dinas Tenaga Kerja dan Transmigrasi Provinsi Jawa Tengah dalam melakukan pengawasan adalah pengurangan jumlah pegawai pengawas, sejak tahun 2017 jumlah pegawai pengawas mengalami penurunan, yang mana pada Tahun 2014 berjumlah 585 pegawai sedangkan pada Tahun 2017 hanya berjumlah 154 pegawai. Konsekuensinya kinerja pegawai pengawas dan jumlah temuan pelanggaran ketenagakerjaan mengalami penurunan. Lalu hambatan yang selanjutnya yaitu kurangnya dana operasional, Hambatan yang terakhir yaitu kurang terpenuhinya faktor sarana dan prasarana, setelah adanya pengalihan kewenangan pengawasan ke provinsi pegawai pengawas tidak mendapatkan sarana dan prasarana yang memadai. Padahal dengan ditariknya pegawai pengawas dari kabupaten/kota ke provinsi tentu membutuhkan dana yang lebih untuk biaya transfortasi dan konsumsi. Pegawai yang berada jauh di luar kota pun mereka tidak mendapatkan fasilitas penginapan hal ini tentu juga berbahaya untuk keselamatan dan kesehatan mereka yang harus menempuh perjalanan jauh.

Kepada Pemerintah Pusat dan Pemerintah Daerah guna terwujudnya optimalisasi pengawasan ketenagakerjaan, maka diperlukan upaya penambahan jumlah sumber daya manusia dan alokasi dana. Penambahan sumber daya manusia yaitu tenaga pengawas ketenagakerjaan dan pengolah data pengawasan ketenagakerjaan serta jumlah penyidik pegawai negeri sipil (PPNS). Selain itu perlunya pemerintah daerah untuk memberikan ketersediaan anggaran yang cukup, sehingga diharapkan penegakan hukum ketenagakerjaan melalui pengawasan ketenagakerjaan dapat dilakukan sesuai dengan aturan. 
Kepada Pemerintah Daerah untuk membentuk suatu budaya masyarakat dan aparat pemerintah, termasuk pegawai pengawas ketenagakerjaan yang sadar akan hukum. Maka Pemerintah Daerah harus membentuk pegawai pengawas yang sadar hukum terlebih dahulu, supaya dapat memberikan contoh kepada masyarakat. Dikaitkan dengan berjalannya pengawasan ketenagakerjaan berarti masyarakat dan pegawai pemerintah harus turut serta dalam pelaksanaan pengawasan, dengan adanya peran masyarakat di sekitar perusahaan yang turut mengawasi tentu akan membantu peran pemerintah untuk mewujudkan kesejahteraan dan keadilan.

\section{Daftar Pustaka}

Ali Muhammad. 2009. Pendidikan Untuk Pembangunan Nasional Menuju Bangsa Indonesia yang Mandiri dan Berdaya Saing Tinggi. Bandung: PT Imperial Bakti Utama

Badan Pusat Statistik, Jumlah Perusahaan di Jawa Tengah-skala kecilmenengah, Http://semarangkota.bps.go.id. Diakses pada 15 Januari 2019 Pukul 13.20 WIB

Bungin Burhan. Metode Penelitian Kuantitatif. Jakarta: Kencana. 2011

Dinas Tenaga Kerja dan Transmigrasi Provinsi Jawa Tengah. Tabel Data Jumlah Pemeriksaan Pengawas Ketenagakerjaan Tahun 2014 Di Seluruh Jawa Tengah.

Indriana. Pelaksanaan Tugas DInas Tenaga Kerja Dalam Pengawasan Keselamatan Dan Kesehatan Kerja Di Kota Makassar.2008. Hal.4

Mas'ud Said, Arah Baru Otonomi di Indonesia, UMM Press, Malang: 2008, hlm 58

Moh. Nazir, Metode Penelitian, Jakarta:Ghalia Indonesia, 2003, hlm. 55.

Nur Diantoro dan Bambang Supomo, Metodologi Penelitian Bisnis Untuk Akuntansi \& Manajemen, Yogyakarta: BPFE-Yogyakarta, 1999, hlm. 147

Peraturan Menteri Tenaga Kerja Nomor 33 Tahun 2016 tentang Tata Cara Pengawasan Ketenagakerjaan

Peraturan Menteri Tenaga Kerja Nomor: PER-04/MEN/1994 tentang Tunjangan Hari Raya Keagamaan Bagi Pekerja di Perusahaan

Peraturan Presiden Nomor 21 Tahun 2010 tentang Pengawasan Ketenagakerjaan

Rusli Hardijan. 2009. Hukum Ketenagakerjaan. Jakarta: Ghalia Indonesia

Safri Nugraha. Hukum Administrasi Negara: Edisi Revisi, Center For Law and Good Governance Studies (CLGSFHUI). Jakarta: Ghalia Indonesia. 2007

Soekanto, Soerjono dan Sri Mamudji. 2004. Penelitian Hukum Normatif Suatu Tinjauan Singkat. Jakarta: PT. Raja Grafindo Persada. 
Sonhaji. "Analisis Putusan Mahkamah Agung Nomor 501 K/ PDT.SUS-PHI/ 2016 Tentang Pemutusan Hubungan Kerja", Administrative Law \& Governance Journal, Vol.1 Edisi Khusus I 2018.

Suhartoyo, "Penguatan Organisasi Buruh / Pekerja Sebagai Sarana Perlindungan Buruh" , Administrative Law \& Governance Journal, Vol.1 Edisi 4, November 2018.

Suhartoyo. Perlindungan Hukum Bagi Pekerja Peserta BPJS Kesehatan di Rumah Sakit. Adminitrative Law \& Governance Journal Vol. 1 Edisi 2 Mei 2018

Sunggono, Bambang. Metodologi Penelitian Hukum, (Jakarta: PT. Raja Grafindo Persada, 2003),

Undang-Undang Dasar Negara Repulik Indonesia Tahun 1945

Undang-undang Nomor 13 Tahun 2003 Tentang Ketenagakerjaan

Undang-Undang Nomor 21 Tahun 2003 tentang Pengesahan ILO Convention No. 81 Concerning Labour Inspection In Industry And Commerce (Konvensi ILO No. 81 Mengenai Pengawasan Ketenagakerjaan Dalam Industri Dan Perdagangan)

Undang-Undang Nomor 23 Tahun 2014 Tentang Pemerintahan Daerah

Widya Astuti, "Pengaruh Perilaku Kepemimpinan pada Kinerja Pegawai Dinas Tata Kota Pekanbaru", Jurnal Ilmu Administrasi Negara, Program Studi Ilmu Administrasi PPS Universitas Riau, Volume 8, No. 2, Juli 2008, 